\title{
Hemşirelik Bölümündeki Öğrencilerin Afet Konusundaki Bilgi ve Bilinç Düzeyleri
}

\author{
Sezer $\mathrm{AVCl}^{1 \star}$, Betül KAPLAN ${ }^{1}$ ve Tülay ORTABAĞ ${ }^{1}$
}

Öz

Bu çalışmanın amacı hemşirelik bölümünde okuyan öğrencilerin afet konusundaki bilgi ve bilinç düzeylerini belirlemektir. Araştırma Gaziantep ilinde yer alan bir vakıf üniversitesinin Sağlık Bilimleri Fakültesi Hemşirelik Bölümü’nde öğrenim gören 330 öğrenciden 268 öğrenciye uygulandı. Araştırma verileri 31 sorudan oluşan soru formuyla, Şubat-Mart 2019 tarihlerinde toplandı. Öğrencilerin yaş ortalaması $22.07 \pm 2.44$ (19-39)'dir. Afet denilince ilk akla gelenin \%81.0 gibi en yüksek oranda deprem olduğu belirtildi. Öğrencilerin \%92.2 gibi büyük bir oranda kendilerinin ve çevresinin afete hazırlıklı olmadığını, \%86.6'sının afet acil durum çantasının olmadığını ve \%75.4'ü afet durumunda yaşadıkları yerde alternatif barınma imkanlarının olmadığını belirtti. Birinci, ikinci, üçüncü ve dördüncü sınıfta olan öğrencilerin en yüksek oranda afetin tanımını "Gerek doğal kaynaklı olsun gerekse insan kaynaklı olsun afet bireyleri, kurumları, eşyaları ve doğayı etkilemekte, hatta yıkımlara yol açmaktadır" belirttikleri tespit edildi. Öğrencilerin afet ve/veya olağan dışı durumlarla ilgili bir tatbikatta görev almak istedikleri saptandı $(p=0.895)$. Son sınıftaki öğrencilerin \%82.7 oranında diğer sınıflardaki öğrencilere göre afet hakkında eğitimli oldukları bulundu $(p=0.000)$. Çalışmamızda hemşirelik öğrencilerinin afet konusunda bilgili oldukları görüldü. Ancak yüksek bir oranda kendilerinin ve çevresinin afetlere hazırıklı olmamasına, yaşanılan yerde afet acil durum çantasının olmamasına ve alternatif barınma imkanlarının olmamasına bağlı olarak öğrencilerin bilinç düzeylerinin yetersiz olduğu görüldü. Afetlere karşı oluşturulacak ulusal bilincin ilköğretim çağındaki çocuklardan başlanarak toplumun bütün yaş kademelerine verilmesi düşüncesindeyiz.

Anahtar Kelimeler: Afet, Afet konusundaki bilgi ve bilinç düzeyi.

\section{The Level of Knowledge and Awareness of Nursing Students about Disasters}

\begin{abstract}
The aim of this study is to determine the level of knowledge and awareness about disaster of the students studying in the nursing department. The study was applied to 268 students from 330 students studying at the Faculty of Health Sciences Nursing Department of a foundation university in Gaziantep. Research data were collected in February-March 2019 with a question form consisted of 31 questions. The mean age of the students was 22.07 \pm 2.44 (1939). When it comes to disaster, the first thing that comes to mind is the highest rate of earthquakes such as $81.0 \%$. A large majority of the students (92.2\%) stated that they and their surroundings were not prepared for a disaster, $86.6 \%$ did not have a disaster emergency bag and $75.4 \%$ had no alternative accommodation facilities in case of a disaster.
\end{abstract}

\footnotetext{
${ }^{1}$ Hasan Kalyoncu Üniversitesi Sağlık Bilimleri Fakültesi, Hemşirelik Bölümü, Gaziantep, Türkiye

* İlgili yazar / Corresponding author: sezer.avci@hku.edu.tr

Gönderim Tarihi / Received Date: 13.09.2019

Kabul Tarihi / Accepted Date: 04.06.2020

Bu makaleye atıf yapmak için- To cite this article Avcı, S., Kaplan, B., \& Ortabağ, T. (2020). Hemşirelik Bölümündeki Öğrencilerin Afet Konusundaki Bilgi ve Bilinç Düzeyleri. Resilience, 89-101. .
} 
It was found that the students in the first, second, third and fourth grades stated the definition of disaster at the highest rate "Disasters, whether caused by nature or humans, affect and even damage individuals, institutions, objects and natüre". It was confirmed that the students wanted to take part in drills related to disaster and/or unusual situations $(p=0.895) .82 .7 \%$ of final-year students were found to be educated about disasters compared to students in other grades $(p=0.000)$. In the present study, it was revealed that nursing students were knowledgeable about disasters. However, it was seen that the students' level of consciousness was insufficient due to the high rate of not being prepared for disasters, the presence of a disaster emergency bag and the lack of alternative accommodation facilities. We believe that a nation-wide awareness about the disasters can be raised starting from the primary schools level to all ages in the society.

Keywords: Disaster, the level of knowledge and awareness about disasters.

\section{GíRiş}

Afetler insanlık tarihi boyunca karşımıza çıkmıştır. Afetlerin insan ve toplum sağlığı üzerinde de ciddi olumsuz etkiler yaptığı da görülmüştür. Afetler, toplum için bir ayna görevi yaparlar. Afetler, toplumların ve dolayısıyla insanların kendilerini bu süreçte nasıl yönettiklerini ve kaynaklarını nasıl tahsil edip kullanacaklarını sergilemektedir. Bu nedenle bir tehlike gelişmiş bir ülkede herhangi bir soruna yol açmazken, geri kalmış veya gelişmekte olan ülkelerde bazı sorunlara yol açabilir (Güler ve Akın, 2015). Ülkemiz topraklarının ise \%90'dan fazlası da deprem tehlikesi ile karşı karşıyadır. Ayrıca ülkemiz büyük çaplı afetlerin meydana gelme açısından da dünya ülkeleri içerisinde de ilk sıralardadır (Yılmaz, 2012). Afetler doğal, teknolojik veya insan kökenli olaylar olarak gerçekleşmektedir. Bu durumda herhangi bir afetin olması insanlar için fiziksel, ekonomik ve sosyal kayıplara neden olacaktır. Ayrıca normal yaşamı ve insan faaliyetlerini durdurarak veya kesintiye uğratarak toplulukları olumsuz etkileyecek olaylar olarak da karşımıza çıkacaktır (Gülkan vd., 2003; Limoncu ve Bayülgen, 2005).

Ülkemizde afetlerin sık sık görülmekte olduğu ve bu afetlerin etkilerinin de uzun süre devam ettiği bilinmektedir. Afetler ülkemizde çok sık ve etkili olarak meydana gelmesine rağmen toplumun bu konudaki duyarlılığı ve eğitimi yeterli düzeyde değildir. Ayrıca yaşanan afet sonrası yöneticilerin, yardım ekiplerinin ve sivil toplum kuruluşlarının afete müdahale etmesi uzun sürecektir. Bu nedenle afete uğramadan önce toplumun ve kişilerin afete hazırlıklı olması ve gerekli önlemleri alabilmeleri için bu konuda bilgili ve bilinçli olmaları çok önemlidir (Meral, 2014). Kişilerin afet gibi öngörülemeyen olaylarla başa çıkabilme konusundaki davranışları, bu duruma hazırlıklı olma, bilgi ve bilinç düzeyleri ile yakından ilişkilidir (Arslan, 2016).

Toplumun afetlerle daha etkili mücadele etmesi yönünde kişilerin bilgi ve bilinç düzeylerini arttırmak için afet durum eğitimleri verilmektedir. Ülkemizde afet durum eğitimleri ilk kez 1996 yılında afet ve olağanüstü durumlarla ilgili sağlık çalışanlarına el kitabı yayınladıktan sonra Türk Tabipler Birliği (TTB) tarafından verilmeye başlanmıştır ve halen de bu eğitimler verilmektedir (Aslan, 2009). Sağlık Bakanlığı Temel Sağlık Hizmetleri Genel Müdürlüğü tarafından, 2004 yılında "Afetlerde Sağlık Organizasyonu Projesi" adı altında Ulusal Medikal Kurtarma Ekipleri (UMKE) oluşturarak eğitmiştir. Bu süreçte yine 2008'den itibaren afet konusunda tüm illerde 112 ekiplerine eğitimler verilmeye de başlanmıştır (Afetlerde Sağlık Organizasyonu Projesi). Ülkemizdeki iller, Sağlık Bakanlığı Afet ve Acil Durum Yönetimi Daire Başkanlığı'na (AFAD) bağlı olarak 21 bölgeye ayrılmıştır. Bu bölgelerde, UMKE eğitimleri çeşitli aralıklarla verilmektedir. Bu eğitim programı 4 gün teorik ve 1 günde uygulama olarak verilmektedir. Bu eğitimin içeriği ise; temel ve ileri yaşam desteği, enkaz çalışmaları, olay yeri yönetimi ve triyaj, çoklu yaralanmalı kazalara müdahale eğitimi, temel 
kampçılık ve hayatı idame ettirme, alternatif atelleme ile hasta/yaralı sabitleme, sedyeleme ve taşıma teknikleri, medikal kurtarma şeklindedir (Yavuz, 2014).

Ülkemizde afetlerle ilgili olarak görev yapan İçişleri Bakanlığı'na bağı Sivil Savunma Genel Müdürlüğü, Bayındırlık ve İskân Bakanlığı'na bağlı Afet İşleri Genel Müdürlüğü ve Başbakanlık’a bağlı Türkiye Acil Durum Yönetimi Genel Müdürlüğü kapatılarak 2009 yılında çıkarılan 5902 sayılı yasa ile Başbakanlık'a bağlı Afet ve Acil Durum Yönetimi Başkanlığı (AFAD) kurulmuştur. Böylelikle afetlerle ilgili tüm yetki ve sorumluluklar tek bir çatı altında toplanmıştır. AFAD; afetlere müdahale edilmesi ve afet sonrasındaki iyileştirme çalışmalarının süratle tamamlanması amacıyla gereken faaliyetlerin planlanmasını, yönlendirilmesini, desteklenmesini, koordine edilmesini ve etkin uygulanmasını sağlayan bir kuruluştur. Ayrıca, ülkenin tüm kurum ve kuruluşları arasında işbirliğini sağlayan çok yönlü bu alanda kaynakların rasyonel kullanımasını sağlayan, faaliyetlerinde disiplinler arası çalışmayı esas alan, iş odaklı, esnek ve dinamik bir yapıyı da teşkil etmektedir (Afet Farkındalığı ve Afetlere Hazırlık Araştırması, 2014).

Ülkemizde afet bilgi ve bilinç düzeyinin ölçüldüğü çalışmalarda, halkın afet konusundaki bilgi ve bilinç düzeyinin düşük olduğu belirlenmiştir. Bu çalışmalarda halkın afet bilinç ve bilgi düzeyinin artırılmasının afetlerin yıkıcı sonuçlarının önlenmesi için gerekli olduğuna vurgu yapılmıştır (İnal vd., 2012; Meral, 2014; Erkal ve Değerliyurt, 2009). Ronan ve Johnston'un 2003 yılındaki çalışmalarında, Lazarus ve Folkman'a göre dikkatsizlik ve bilgi eksikliğinin afet durumunda tepki vermede negatif etkisi olduğu belirtilmektedir. Aynı çalışmada, Sjoberg'e göre dikkatsizlik ve bilgi eksikliğinin korkuyu arttırdığı da bildirilmektedir. Ülkemizde 2014 yılında yapılan "Afet Farkındalığı ve Afete Hazırlık Araştırması"na göre; araştırmaya katılanların \%61'inin yaşadıkları bölgede meydana gelebilecek afetler konusunda endişe yaşadıkları bulunmuştur. "Afet Farkındalığı ve Afete Hazırlık Araştırması" AFAD tarafından, Türkiye'de bugüne kadar afet farkındalığı ve afete hazırlık konularında gerçekleştirilmiş en geniş kapsamlı araştırmasıdır (Afet Farkındalığı ve Afetlere Hazırlık Araştırması, 2014).

Bireylerin ve toplumların kaçınamayacakları ve tamamen önleyemeyecekleri olan afetlere karşı gerekli önlemlerin alınması ve bu sayede afetlerle yaşamanın öğrenilmesi gerekmektedir (Yılmaz, 2012). Ülkemizde yaşayan tüm insanların, ülkemizde sık sık karşımıza çıkan afetlerle ilgili bilgi ve bilinç düzeylerinin tespit edilmesi gerekmektedir. Afetler nedeniyle yaşanan tüm kayıpların önlenmesi ve ortadan kaldırılması için toplumun bilgilendirilmesi ve bilinç düzeylerinin arttırılması gerekmektedir. Toplumun bilinçlendirilmesi ve eğitilmesi için ilk olarak toplumdaki genç nüfusun da afetlerle ilgili bilgi ve bilinç düzeyleri belirlenmelidir (Meral, 2014). Gençlerde ise afetler ile ilgili bilgi düzeylerinin belirlenmesi ve buna yönelik çalışmaların yapılması toplumsal acil yönetimi için ek olarak destek sağlayacaktır (İnal vd., 2012). Özellikle afet yönetiminde birçok disiplinin bir arada çalışması gerekir. Bu işleyişi kolaylaştırmak için standart terminoloji ve haberleşme kullanılmaktadır. Afet yönetiminde başarılı olabilmek için hem toplumun özellikleri ve hem de o toplumu etkileyebilecek tehlikeler hakkında yeterli bilgiye sahip olmak gerekir (Güler ve Akın, 2015). Ayrıca, afette görev alacak sağlık personelinin eğitilmesi gerektiği ve bu eğitimin de hem mezuniyet öncesi hem de mezuniyet sonrası olması gerektiği belirtilmektedir (Altıntaş, 2005). Sağlık alanından mezun olacak genç nüfusun afetlerle ilgili bilgi ve bilinç düzeylerinin tespit edilmesi afet sonrasındaki sürecin yönetiminin daha etkili olmasını sağlayacaktır. Bundan sonraki aşamada, üniversitede sağlık alanında öğrenim gören öğrencilere bu konudaki eğitim içerikleri bu çalışmalardan elde edilen bilgiler doğrultusunda oluşturulabilecektir. Dolayısıyla bu çalışma da hemşirelik bölümünde okuyan öğrencilerin afet konusundaki bilgi ve bilinç düzeylerini saptamak amacıyla yapılmıştır. 


\section{GEREÇ-YÖNTEM}

\subsection{Araştırmanın tipi, evren ve örneklemi}

Tanımlayıcı tipteki araştırma, Şubat-Mart 2019 tarihlerinde Gaziantep ilinde bir vakıf üniversitesinin Sağlık Bilimleri Fakültesi Hemşirelik Bölümü’nde öğrenim gören öğrencilere uygulandı. Hemşirelik bölümünde belirtilen tarihler arasında öğrenim gören 330 öğrenci bulunmaktadır. Araştırma, gönüllülük esasına dayanmaktadır ve buna bağlı olarak araştırmaya katılmak istemeyen, devamsızlık yapan bazı öğrenciler olduğu için 268 öğrenci çalışmanın örneklemini oluşturmaktadır.

\subsection{Veri toplama araçları ve veri toplama yöntemi}

Çalışmada, araştırmacılar tarafından literatür taraması sonucu oluşturulan 31 soruluk anket formu uygulandı. Anket formu 1., 2., 3. ve 4.sınıfta okuyan öğrencilere uygulandı. Bir ders saatinde dersin sorumlu öğretim üye/elemanından izin alındıktan ve öğrencilere çalışma hakkında bilgi (çalışmanın amacı ve bilgilerinin hiç bir yerde hiç bir şekilde kullanılmayacağı) verildikten sonra anket formu uygulandı. İlk dört soru yaş, cinsiyet, kaçıncı sınıfta olduğu ve ikamet yeri sorularından oluşturmaktadır. Diğer 27 soru ise katılımcıların afetler konusundaki bilgi ve bilinç durumlarını belirlemeye yönelik (afetin tanımı, afet olduğunda olay yerine müdahale etmesi gereken ekip, afetlere ilişkin bilgilere hangi kaynaktan ulaşma, yaşanılan şehrin afet yönünden riski, afet yaşama durumu vs.) sorulardır.

\subsection{Araştırmanın etik yönü}

Araştırmanın uygulaması için gerekli izin, Hasan Kalyoncu Üniversitesi Sağlık Bilimleri Fakültesi Girişimsel Olmayan Araştırmalar Etik Kurulu'ndan alındı. Araştırmanın yapıldığı üniversiteden de yazılı izin alındı. Araştırmaya katılmaya gönüllü olan öğrencilerin yazılı bilgilendirilmiş onamı alındı.

\subsection{Verilerin analizi ve değerlendirilmesi}

Veri tabanı oluşturulmasında ve analizlerde SPSS (Statistical Package for Social Sciences) 20.0 Windows paket programı kullanıldı. Sonuçlar \%95 güven aralığında anlamlılı $p<0.05$ düzeyinde değerlendirildi. Tablolar yorumlanırken " $p$ " 0.05 ' ten küçük olanlar istatistiksel olarak anlamlı, büyük olanlar anlamlı değil olarak yorumlandı. Araştırmaya katılan öğrencilerin tanıtıcı bilgilerine ilişkin verilerin; sayı-yüzde dağılımları ve oranların karşılaştırmasında ise ki-kare testi yapıldı.

\section{BULGULAR}

Öğrencilerin yaş ortalaması 22.07 \pm 2.44 (19-39)'dur. Araştırmaya katılan öğrencilerin sosyodemografik özellikleri Tablo 1'de belirtilmiştir. Tablo 1'e göre; araştırmaya katılan öğrencilerin \%48.9'u 22-24 yaş arasındadır. Öğrencilerin \%69.4'ü kız ve \%30.6'sı erkektir. Araştırmaya katılanların \%25.4'ü birinci sınıf, \%20.9'u ikinci sınıf, \%23.5'i üçüncü sınıf ve \%30.2'si dördüncü sınıf lisans öğrencisidir. Öğrencilerin \%74.3'ünün ikamet yerinin il olduğu görülmektedir.

Öğrencilere afetin tanımının hangisi olduğu sorulduğunda; öğrencilerin \%48.1 gibi en yüksek oranda 'Gerek doğal kaynaklı olsun gerekse insan kaynaklı olsun afet bireyleri, kurumları, eşyaları ve doğayı etkilemekte, hatta yıkımlara yol açmaktadır' ifadesinin olduğu tespit edilmiştir. Öğrencilerin \%3.7 gibi en az oranda 'Çok sayıda yaralı ve ölünün meydana geldiği ve maddi kayıpların yaşandığı olaylara afet denir' tanımını belirttikleri bulunmuştur (Tablo 2).

Araştırmaya katılan öğrenciler, afet denilince ilk akla gelenin $\% 81.0$ gibi en yüksek oranda deprem olduğunu belirtmiştir. Öğrencilere afetlerin önemlilik derecesine göre en önemli bulduklarına 1'den başlayarak puan vermeleri sorulduğunda; depremi \%54.1, savaşlar ve 
çatışmaları \%20.5, sel ve su baskınını \%5.2 oranında en önemli afet olarak değerlendirdikleri bulunmuştur (Tablo 2).

Öğrencilerin afet olduğunda olay yerine gitmesi gereken ekibi belirtme durumu Tablo 2'de yer almaktadır. Tablo 2'ye göre; öğrencilerin \%79.9 gibi en yüksek oranda bir afet olduğunda olay yerine müdahale etmesi gereken ekibin AFAD \%16.0 oranında ise UMKE olduğunu belirttikleri tespit edilmiştir.

Araştırmaya katılan öğrencilerin afet konusundaki bilgi düzeylerinin dağılımı Tablo 3'te sunulmuştur. Tablo 3'e göre; öğrencilerin afetle ilgili bilgi kaynağına yüksek oranlarda \%66.4'ünün internetten ve \%64.9'unun televizyondan ulaştıkları belirlenmiştir. Öğrencilerin \%38.8'i yaşadıkları şehrin afet riski durumundan emin olmadıklarını belirtmiştir. Yaşanılan yerin deprem yönünden fiziki açıdan risk durumu sorulduğunda; \%50.7 gibi yüksek oranda 'orta riskli', eğitim gördükleri üniversitenin deprem yönünden fiziki açıdan risk durumu sorulduğunda ise \%47.0 gibi yüksek oranda da 'orta riskli' olarak gördükleri belirlenmiştir. Öğrencilerin \%60.8'inin afet hakkında eğitim aldıkları saptanmıştır ve \%91.4'ü de afetle ilgili konuların lisans eğitimlerinde bulunduklarını belirtmiştir. Ayrıca öğrencilerin \%73.1'inin herhangi bir afet yaşamadığı ve \%79.5'inin afet ve/veya olağan dışı durumlarla ilgili tatbikatta görev almadığı tespit edilmiştir. Öğrencilerin \%92.2 gibi büyük bir oranda kendilerinin ve çevresinin afete hazırlıklı olmadığını, \%86.6'sının afet acil durum çantasının olmadığını ve $\% 75.4$ 'ü afet durumunda yaşadıkları yerde alternatif barınma imkanlarının olmadığını belirttikleri bulunmuştur.

Öğrencilerin sınıf durumları ile afet bilinçlilik durumları arasındaki ilişki Tablo 4'te gösterilmiştir. Tablo 4'e göre öğrencilerin sınıf durumlarıyla afet hakkında eğitim alma durumları, yaşadıkları yerde afet acil durum çantası bulundurma durumları, kendilerinin ve çevresinin afete daha hazırlıklı olduklarını düşünme durumları arasında istatistiksel olarak anlamlı farklılıklar olduğu tespit edilmiştir $(p<0.05)$.

Tablo 1. Öğrencilerin Sosyodemografik Özellikleri $(n=268)$

\begin{tabular}{|l|c|c|}
\hline Sosyodemografik Özellikleri & Sayı & Yüzde \\
\hline Yaş grubu & 116 & \\
$19-21$ & 131 & 43.3 \\
$22-24$ & 21 & 48.9 \\
$\geq 25$ & & 7.8 \\
\hline Cinsiyet & 186 & \\
Kız & 82 & 69.4 \\
Erkek & & 30.6 \\
\hline Kaçıncı sınıfta okuma durumu & 68 & \\
1.sınıf & 56 & 25.4 \\
2.sınıf & 63 & 20.9 \\
3.sınıf & 81 & 23.5 \\
4. sınıf & & 30.2 \\
\hline İamet yeri & 199 & 74.3 \\
İl & 61 & 22.7 \\
İlçe & 8 & 3.0 \\
Köy & & \\
\hline
\end{tabular}


Tablo 2. Öğrencilerin Afet İle ilgili Görüşlerinin Dağılımı ( $n=268)$

\begin{tabular}{|l|c|c|}
\hline Afet İle İlgili Görüşleri & Sayı & Yüzde \\
\hline Afet Tanımları & & \\
\hline $\begin{array}{l}\text { Gerek doğal kaynaklı olsun gerekse insan kaynaklı olsun afet bireyleri, } \\
\text { kurumları, eşyaları ve doğayı etkilemekte, hatta yıkımlara yol açmaktadır. }\end{array}$ & 129 & 48.2 \\
\hline $\begin{array}{l}\text { Afet, bir toplumu ya da çevreyi olumsuz olarak etkileyen doğal kaynaklı } \\
\text { darbedir. }\end{array}$ & 62 & 23.1 \\
\hline $\begin{array}{l}\text { Herhangi bir tehlikenin can, mal, çevre, ekonomi ve kültürel varlıklar üzerinde } \\
\text { yaratığı kötü etkilerle baş etmeye yerel imkânların yetmediği durumlardır. }\end{array}$ & 49 & 18.3 \\
\hline Afet, oluş zamanı belli olmayan kitlesel yaşam kayıplarına denir. & 18 & 6.7 \\
\hline $\begin{array}{l}\text { Çok sayıda yaralı ve ölünün meydana geldiği ve maddi kayıpların yaşandığı } \\
\text { olaylara afet denir. }\end{array}$ & 10 & 3.7 \\
\hline İlk Akla Gelen Afet Türü & & \\
\hline Deprem & 217 & 81.0 \\
\hline Tsunami & 15 & 5.6 \\
\hline Sel ve su baskını & 9 & 3.4 \\
\hline Heyelan-çığ & 9 & 3.4 \\
\hline Nükleer-Santral-Teknolojik Kazalar & 6 & 2.2 \\
\hline Diğer (Fırtına/Hortum, Patlama-Yangın, Savaşlar ve çatışmalar ve Kuraklık) & 12 & 4.4 \\
\hline En Önemli Gördükleri Afet Türü & & \\
\hline Deprem & 145 & 54.1 \\
\hline Savaşlar ve çatışmalar & 55 & 20.5 \\
\hline Sel ve su baskını & 14 & 5.2 \\
\hline Nükleer-Santral-Teknolojik Kazalar & 13 & 4.9 \\
\hline Patlama-Yangın & 13 & 4.9 \\
\hline Tsunami & 10 & 3.7 \\
\hline Diğer (Kuraklık, Heyelan-çığ, Fırtına/Hortum) & 18 & 6.7 \\
\hline Olay Yerine Gitmesi Gereken Ekip & & \\
\hline AFAD (Afet ve Acil Durum Yönetimi Başkanlığı) & 214 & 79.8 \\
\hline UMKE (Ulusal Medikal (Tıbbi) Kurtarma Ekipleri ) & 43 & 16.0 \\
\hline Ambulans & 9 & 3.4 \\
\hline Diğer (STK (Sivil Toplum Kuruluşları) ve Jandarma) & 2 & 0.8 \\
\hline
\end{tabular}

Tablo 3. Öğrencilerin Afet Konusundaki Bilgi Düzeylerinin Dağııımı $(n=268)$

\begin{tabular}{|c|c|c|}
\hline \multirow{2}{*}{\multicolumn{3}{|c|}{ Afetle ilgili bilgi kaynağına ulaşma durumu* }} \\
\hline & & \\
\hline Aile & 57 & 21.3 \\
\hline Öğretmen & 79 & 29.5 \\
\hline Arkadaş & 14 & 5.2 \\
\hline İnternet & 178 & 66.4 \\
\hline Televizyon & 174 & 64.9 \\
\hline Yazılı basın & 68 & 25.4 \\
\hline Yaşayarak & 22 & 8.2 \\
\hline \multicolumn{3}{|l|}{ Yaşanılan şehrin afet risk durumu } \\
\hline Evet & 66 & 24.6 \\
\hline Hayır & 98 & 36.6 \\
\hline Emin değilim & 104 & 38.8 \\
\hline \multicolumn{3}{|l|}{$\begin{array}{l}\text { Yaşanılan yerin deprem yönünden fiziki açıdan } \\
\text { risk durumu }\end{array}$} \\
\hline Az riskli & 84 & 31.3 \\
\hline Orta riskli & 136 & 50.7 \\
\hline Çok riskli & 37 & 13.8 \\
\hline Riskli değil & 11 & 4.2 \\
\hline $\begin{array}{l}\text { Üniversitenin deprem yönünden fiziki açıdan } \\
\text { risk durumu }\end{array}$ & & \\
\hline
\end{tabular}




\begin{tabular}{|c|c|c|}
\hline $\begin{array}{l}\text { Az riskli } \\
\text { Orta riskli } \\
\text { Çok riskli } \\
\text { Riskli değil }\end{array}$ & $\begin{array}{r}81 \\
126 \\
45 \\
16\end{array}$ & $\begin{array}{r}30.2 \\
47.0 \\
16.8 \\
6.0\end{array}$ \\
\hline $\begin{array}{l}\text { Afet hakkında eğitim alma durumu } \\
\text { Evet } \\
\text { Hayır }\end{array}$ & $\begin{array}{l}163 \\
105\end{array}$ & $\begin{array}{l}60.8 \\
39.2\end{array}$ \\
\hline $\begin{array}{l}\text { Afet ile ilgili konuların lisans eğitiminde } \\
\text { bulunma durumu } \\
\text { Evet } \\
\text { Hayır }\end{array}$ & $\begin{array}{c}245 \\
23\end{array}$ & $\begin{array}{r}91.4 \\
8.6\end{array}$ \\
\hline $\begin{array}{l}\text { Afet yaşama durumu } \\
\text { Evet } \\
\text { Hayır }\end{array}$ & $\begin{array}{c}72 \\
196\end{array}$ & $\begin{array}{l}26.9 \\
73.1\end{array}$ \\
\hline $\begin{array}{l}\text { Afet ve/veya olağan dışı durumlarla ilgili } \\
\text { tatbikatta görev alma durumu } \\
\text { Evet } \\
\text { Hayır }\end{array}$ & $\begin{array}{c}55 \\
213\end{array}$ & $\begin{array}{l}20.5 \\
79.5\end{array}$ \\
\hline $\begin{array}{l}\text { Sizin ve çevrenizin afete hazırlıklı olduğunu } \\
\text { düşünme durumu } \\
\text { Evet } \\
\text { Hayır }\end{array}$ & $\begin{array}{c}21 \\
247\end{array}$ & $\begin{array}{c}7.8 \\
92.2\end{array}$ \\
\hline $\begin{array}{l}\text { Yaşanılan yerde afet acil durum çantası } \\
\text { bulundurma durumu } \\
\text { Evet } \\
\text { Hayır }\end{array}$ & $\begin{array}{c}36 \\
232\end{array}$ & $\begin{array}{l}13.4 \\
86.6\end{array}$ \\
\hline $\begin{array}{l}\text { Yaşanılan yerde alternatif barınma imkanını } \\
\text { belirtme durumu } \\
\text { Evet } \\
\text { Hayır }\end{array}$ & $\begin{array}{c}66 \\
202\end{array}$ & $\begin{array}{l}24.6 \\
75.4\end{array}$ \\
\hline
\end{tabular}

*n katlanmıştır.

Tablo 4. Öğrencilerin Sınıf Durumları ile Afet Bilinçlilik Durumları Arasındaki Ilişsi $(n=268)$

\begin{tabular}{|c|c|c|c|c|c|c|c|c|c|c|c|c|}
\hline \multirow{3}{*}{$\begin{array}{l}\text { Afet ve/veya olağan dışı } \\
\text { durumlarla ilgili tatbikatta } \\
\text { görev almayı isteme durumu }\end{array}$} & \multicolumn{12}{|c|}{ Sınıf Durumları } \\
\hline & \multicolumn{2}{|c|}{ 1.sınıf } & \multicolumn{2}{|c|}{ 2.sınif } & \multicolumn{2}{|c|}{ 3.sınıf } & \multicolumn{2}{|c|}{ 4.sınıf } & \multicolumn{2}{|c|}{ Toplam } & \multirow[b]{2}{*}{$x^{2}$} & \multirow[b]{2}{*}{ p } \\
\hline & Sayı & Yüzde & Sayı & Yüzde & Sayı & Yüzde & Sayı & Yüzde & Sayı & Yüzde & & \\
\hline Evet & 55 & 80.9 & 47 & 83.9 & 52 & 82.5 & 64 & 79.0 & 218 & 81.3 & 0.60 & \\
\hline Hayır & 13 & 19.1 & 9 & 16.1 & 11 & 17.5 & 17 & 21.0 & 50 & 18.7 & 6 & 0.895 \\
\hline \multicolumn{13}{|l|}{$\begin{array}{l}\text { Afet hakkında eğitim alma } \\
\text { durumu }\end{array}$} \\
\hline Evet & 22 & 32.4 & 36 & 64.3 & 38 & 60.3 & 67 & 82.7 & 163 & 60.8 & 39.7 & \\
\hline Hayır & 46 & 67.6 & 20 & 35.7 & 25 & 39.7 & 14 & 17.3 & 105 & 39.2 & 11 & 0.000 \\
\hline \multicolumn{13}{|l|}{$\begin{array}{l}\text { Yaşanılan yerde afet acil } \\
\text { durum çantası bulundurma } \\
\text { durumu }\end{array}$} \\
\hline Evet & 10 & 14.7 & 15 & 26.8 & 4 & 6.3 & 7 & 8.6 & 36 & 13.4 & 12.9 & \\
\hline Hayır & 58 & 85.3 & 41 & 73.2 & 59 & 93.7 & 74 & 91.4 & 232 & 86.6 & 99 & 0.005 \\
\hline \multicolumn{13}{|l|}{$\begin{array}{l}\text { Afetlere karşı bireysel } \\
\text { hazırlığın toplumsal hazırlığa } \\
\text { dönüşebileceğini düşünme } \\
\text { durumu }\end{array}$} \\
\hline Evet & 36 & 52.9 & 20 & 35.7 & 36 & 57.1 & 44 & 54.3 & 136 & 50.7 & 6.63 & \\
\hline Hayır & 32 & 47.1 & 36 & 64.3 & 27 & 42.9 & 37 & 45.7 & 132 & 49.3 & 9 & 0.084 \\
\hline \multicolumn{13}{|l|}{$\begin{array}{l}\text { Sizin ve çevrenizin afete } \\
\text { hazırıklı olduğunu düşünme } \\
\text { durumu }\end{array}$} \\
\hline $\begin{array}{l}\text { Evet } \\
\text { Hayır }\end{array}$ & $\begin{array}{c}3 \\
65\end{array}$ & $\begin{array}{c}4.4 \\
95.6\end{array}$ & $\begin{array}{l}10 \\
46\end{array}$ & $\begin{array}{l}17.9 \\
82.1\end{array}$ & $\begin{array}{c}6 \\
57 \\
\end{array}$ & $\begin{array}{c}9.5 \\
90.5\end{array}$ & $\begin{array}{c}2 \\
79\end{array}$ & $\begin{array}{c}2.5 \\
97.5\end{array}$ & $\begin{array}{c}21 \\
247\end{array}$ & $\begin{array}{c}7.8 \\
92.2\end{array}$ & $\begin{array}{c}12.3 \\
70\end{array}$ & 0.006 \\
\hline
\end{tabular}




\section{TARTIŞMA}

$\mathrm{Bu}$ çalışma, hemşirelik bölümünde okuyan öğrencilerin afet konusundaki bilgi ve bilinç düzeylerini belirlemek amacıyla yapılmıştır. Bu bölümde çalışmamızdan elde ettiğimiz veriler literatür bilgileri ile karşılaştırılarak tartışılmıştır.

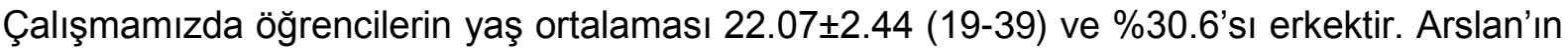
2016 yılında yaptığı çalışmada ise katılımcıların \%44.6'sının erkek, tüm katılımcıların yaş ortalamasının da $21.57 \pm 1.98$ (18-28) olduğu bulunmuştur. Her iki çalışmada da kız öğrencilerin erkeklere göre daha fazla sayıda oldukları görülmektedir. Yaş ortalamaları yönündeki farklıı̆ı̆ın tıp fakültesi öğrencilerinin üniversiteye daha erken yaşlarda yerleşmiş olmalarından kaynaklanmış olabileceği düşünülmektedir.

Çalışmamızda katılımcılara afetin tanımı sizce nedir olarak yöneltilen soruda 'Gerek doğal kaynaklı olsun gerekse insan kaynaklı olsun afet bireyleri, kurumları, eşyaları ve doğayı etkilemekte, hatta yıkımlara yol açmaktadır' ifadesi afetin doğru tanımı olarak kabul edilmiştir. Çalışmamızda öğrencilerin \%48.1 gibi en yüksek oranda bu tanımı belirttikleri bulunmuştur. Arslan'nın 2016 yılındaki yaptığı çalışmada "Etkilenen toplumların bu durumla kendi kaynaklarıyla tek başına başa çıkamamasından dolayı, çok sayıda maddi, çevresel ve insani kayıplarının oluşmasının sonucu olarak toplumsal işleyişin ciddi şekilde aksamasına afet denir" tümcesi basit, sadeleştirilmiş ve doğru afet tanımı olarak kabul edilmiştir. Bu çalışmada katıımcıların afet tanımı ile ilgili soruya verdikleri yanıtlar incelendiğinde; tüm katılımcıların \%41.5'inin doğru seçeneği işaretlediği bulunmuştur. Literatürde çok farklı, birbirinden çeşitli afet tanımlarının olduğu görülmektedir (Gülkan vd., 2003; Limoncu ve Bayülgen, 2005; Arslan, 2016; Başeğmez, 2017; Sevinç vd., 2018). Afetin standartlaşmış, genel bir tanımının olmamasına bağlı olarak her iki çalışmanın afet tanımı cümlesinde de benzer ifadelerin olduğu görülmektedir.

Araştırmaya katılan öğrenciler, afet denilince ilk akla gelenin \%81.0 gibi en yüksek oranda deprem olduğunu belirtmiştir. Öğrencilere afetlerin önemlilik derecesine göre en önemli bulduklarına 1'den başlayarak puan vermeleri sorulduğunda; depremi \%54.1, savaşlar ve çatışmaları \%20.5, sel ve su baskınını \%5.2 oranında en önemli afet olarak değerlendirdikleri bulunmuştur. Işık ve ark.'nın 2012 yılında yaptığı bir çalışmada ülkemizde görülen en sık afet türleri incelendiğinde; ilk sırayı deprem (\%61) almakta, sırasıyla heyelan (\%15) ve sel baskınları (\%14) takip etmektedir. Yapılan bir çalışmada ise deprem \%72.9 oranında katılımcıların aklına ilk gelen afet türüdür. Bunu \%19.8 ile sel-su baskınları şıkkı takip etmektedir (Meral, 2014). Afet ve Acil Durum Yönetimi Başkanlığı tarafından 2014 yılında yapılan Türkiye, Afet Farkındalığı ve Afetlere Hazırlık Araştırması'nda en sık yaşanılan afet türü sorusuna katılımcıların \%56.5 ile deprem şıkkına en yüksek oranda cevap verdikleri saptanmıştır. Öğrencilerin afet olarak en yüksek oranlarda depremi belirtmeleri ülkemizde de sıkça gözüken deprem afetinin olmasından kaynaklanmaktadır. Ayrıca şehrin coğrafik konumundan dolayı da öğrencilerin, ikinci önemli afet türü olarak savaşlar ve çatışmaları belirtikleri düşünülmektedir.

Öğrencilere bir afet olduğunda olay yerine müdahale etmesi gereken ekip sorulduğunda; \%79.9 gibi en yüksek oranda AFAD, \%16.0 oranında ise UMKE olduğunu belirttikleri bulunmuştur. Afet ve Acil Durum Yönetimi Başkanlığı, afet ve acil durumlara ilişkin tek yetkili kurum olup, bir şemsiye kurum anlayışıyla afet ve acil durumun niteliği ve büyüklüğüne göre gerek Genelkurmay Başkanlığı, Dışişleri, Sağlık, Ulaştırma ve Altyapı vb. ilgili diğer bakanlıklar ile gerekse sivil toplum kuruluşları ile işbirliği içerisinde faaliyetlerini sürdürmektedir (AFAD- Hakkında, https://www.afad.gov.tr/tr/2211/AFAD-Hakkinda). Afet ve Acil Durum Yönetimi Daire Başkanlığına bağlı olarak 2004 yılında kurulan UMKE ulusal ve uluslar arası alanda acil, afet ve olağandışı durumlarda 24 saat görev yapabilme 
kapasitesine sahiptir (UMKE Tarihçesi, https://www.umke.org/umke-tarihcesi-s14.html). AFAD'ın daha yüksek oranda bulunmasının bu durumdan kaynaklandığı tahmin edilmektedir.

Araştırmaya katılan öğrencilerin afetlere ilişkin bilgilere ulaşma kaynakları olarak \%66.4 gibi en fazla oranda internet ve \%64.9 oranında da televizyon olduğu tespit edilmiştir. Bu durum, öğrencilerin dolayısıyla gençlerin sosyal medyayı aktif olarak kullandıklarını göstermektedir. Öğrencilerin \%24.6'sı eğitim gördükleri şehrin afet yönünden risk altında olduğunu, \%38.8'i ise emin olmadıklarını ifade etmiştir. Şehrin afet yönünden riskli durumları olarak \%21.2 gibi en fazla oranda deprem, daha az oranlarda \%1.9'u savaş ve \%1.5'i ise sel olarak belirttikleri bulunmuştur. Yaşadıkları yeri de depremler açısından \%50.7 gibi en fazla oranda orta riskli olarak görmektedirler. Gaziantep şehri, 3. derecede deprem bölgesindedir. Yakınındaki il ve ilçelerin deprem merkezlerinin etkisinde kalarak Gaziantep'te küçük depremler olmaktadır. Bu bölgede meydana gelmiş tarihi büyük depremler yoktur. İlin sınırları içerisinde sık olmamakla beraber normal iklim koşullarına göre sel afeti olmaktadır. İlin doğusunda Şanlıurfa, batısında Osmaniye ve Hatay, kuzeyinde Kahramanmaraş, güneyinde Suriye, kuzeydoğusunda Adıyaman ve güneybatısında Kilis illeri bulunmaktadır (Gaziantep İ Çevre Durum Raporu, 2010). Literatürdeki bu bilgilere göre öğrencilerin yaşadıkları şehrin afet ile ilgili ne gibi riskli durumların olduğu yönünde kişisel tahmini bilgi düzeylerinin doğru olduğu görülmektedir. Ayrıca öğrencilerin yaşadıkları yerin afetler yönünden yeterince güvenilir olup olmadığı yönünde sorgulamadıklarını da düşünmekteyiz.

Öğrencilerin, öğrenim gördükleri üniversiteyi de depremler açısından \%47.0 gibi en fazla oranda 'orta riskli' olarak belirttikleri tespit edilmiştir. Üniversitenin risk değerlendirme raporunda tehlike sınıfı olarak az tehlikeli olduğu belirtilmektedir. Tehlikenin ve riskin tamamen ortadan kaldırılması mümkün olmasa da, tehlikenin ve riskin azaltılmasının uygulanan kontrol sistemleri ile sağlanabileceği de raporda bulunmaktadır. Öğrencilerin üniversiteyi depremler yönünden 'orta riskli' belirtmelerinin üniversitenin yerleşim yeri, mimari yapısı ve şehrin afetler ile ilgili durumlarına bağlı olarak tahmin ettikleri düşünülmektedir.

Öğrencilerin \%60.8 oranında afet hakkında eğitim aldıkları ve \%91.4'ünün ise afet ile ilgili konuların lisans eğitimlerinde bulunmasını istedikleri belirlenmiştir. Arslan'ın 2016 yılında yaptığı çalışmada katılımcıların herhangi bir dönemde afet eğitimine katılma durumları sorgulandığında; \%27.4'ünün önceden afet eğitimini aldıkları bulunmuştur. Aynı çalışmada katılımcıların \%80.5'i afet tıbbı eğitimini almak istediklerini belirtmiştir. Mortelmans ve ark.'nın 2015 yılında yaptıkları çalışmada, öğrencilerin \%51'i afet tıbbı eğitimine intiyaç duyduklarını, yine aynı yazarlar tarafından yapılan başka bir çalışmada ise öğrencilerin \%47'si afet tıbbı eğitiminin tıp eğitimi müfredatında olması gerektiğini belirtmişlerdir (Mortelmans vd., 2013). Ronan'ın 2001 yılında, Ronan ve Johnston'un 2003 yılında yaptıları çalışmalarda, adölesanlarda ve ailelerinde afet durumunda baş etmeyi arttırmada verilen afet eğitim programlarının rolü olduğu saptanmıştır. Ayrıca gençlerde afetlere ilişkin bilginin artmasının toplumsal acil yönetimi için ilave destek sağlayabileceği belirtilmiştir. Çalışmamızda da olduğu gibi bu çalışmalardan elde edilen sonuçlara göre sağlık alanında çalışacak olan kişilerin afet hakkında eğitimli olmak istedikleri görülmektedir. Ayrıca çalışmamızda dördündü sınıfta okuyan öğrencilerin diğer sınıflara göre daha yüksek oranda afet eğitimini aldıkları bulundu. Bu durum dördüncü sınıfların 7. yarıyıllarında aldıkları 'Halk Sağlığı Hemşireliği' dersinin müfredatında afet ile ilgili konuların olmasından kaynaklanmaktadır.

Öğrencilerin \%26.9'u afet yaşadıklarını belirtmiştir. Yaşadıkları afetler incelendiğinde; \%24.6 oranında deprem, \%0.4 oranında sel ve \%1.9 oranında ise yangın olduğu bulundu. Yapılan bir çalışmada daha önce afet yaşadığını belirten katılımcıların \%76.5'i deprem afetini, \%6.9'u sel-su baskını afetini yaşadığını belirtmiştir (Meral, 2014). Afet ve Acil Durum Yönetimi Başkanlığı tarafından 2014 yılında yapılan Türkiye, Afet Farkındalığı ve Afetlere Hazırlık 
Araştırması'nda doğrudan bir afete maruz kalan bireylerin \%69.7'sinin deprem afetine, \%11.0'inin ise sel afetine yakalandığı bulunmuştur. Bu araştırmalardan çıkan sonuçların bizim araştırmamızla benzerlik gösterdiği görülmektedir.

Öğrencilerin \%20.5’i de afet ve/veya olağan dışı durumlarla ilgili tatbikatta görev aldıkları belirlenmiştir. Yapılan bir çalışmada da katılımcılara herhangi bir afet tatbikatında yer alıp almadığı sorulduğunda ise \%51.2'sinin afet tatbikatına katılmadıklarını belirtmiştir (Arslan, 2016). Araştırma sonuçları, bu bulguyla benzerdir.

Çalışmamızda birinci, ikinci, üçüncü ve dördüncü sınıflarda olan öğrencilerin çoğunluğunun afet ve/veya olağan dışı durumlarla ilgili tatbikatta görev almayı istedikleri bulunmuştur. Afet durumunda tehlike ve risklerin olumsuz etkilerini en aza indirmek, zamanında hızlı ve etkin bir müdahale için önceden yapılması gereken tüm faaliyetlere hazırlıklı olmak bu konuda öncelikle uygulanması gereken davranıştır (Arslan, 2016). Afet sırasında hem sahada hem de hastanede yaralıların tanı ve tedavisinde başarılı olmak ve ortaya çıkabilecek sorunlara çözüm üretebilmek için her kurumun önceden hazırlamış oldukları bir afet planı ve afet tatbikatının olması gerekmektedir (Işık vd., 2012). Afet eğitimi sırasında eğitim modellerine daha fazla yer verilmesi ve afet tatbikatlarının dönemsel olarak düzenli olarak gerçekleştirilmesinin afet esnasında olabilecek sorunların en aza indirilebileceğine inanmaktayız.

Öğrencilerin \%92.2 gibi büyük bir oranda kendilerinin ve çevresinin afete hazırlıklı olmadığını, \%86.6'sının afet acil durum çantasının olmadığını ve \%75.4'ü afet durumunda yaşadıkları yerde alternatif barınma imkanlarının olmadığını belirtmiştir. Yapılan bir çalışmada katılımcıların \%86.4'ünün herhangi bir afet durumunda bölgelerindeki afet toplanma yerini bilmediklerini, \%86'sının halihazırda kişisel/ailesel afet planlarının olmadığını, \%88.2'sinin ise evlerinde afet-acil durum çantasının bulunmadığını belirtmiştir (Arslan, 2016). İnal ve ark.'nın 2012 yılında meslek yüksek okulu öğrencileri arasında yaptıkları bir çalışmada; katılımcıların sadece \%14.1'inin ailesel/kişisel bir afet planlarının olduğu, $\% 11.3$ 'ünün evlerinde afet-acil durum çantası bulundurdukları rapor edilmiştir. Afet ve Acil Durum Yönetimi Başkanlığı tarafından 2014 yılında yapılan Türkiye, Afet Farkındalığı ve Afetlere Hazırlık Araştırması'nda ( "Sizce Türk toplumu herhangi bir afete karşı ne kadar hazırıklı" sorusuna verilen cevaplar içerisinde en yüksek oranı hazırlıksız ve kesinlikle hazırlıksız sıklarının oluşturduğu \%74.6 oranında olduğu tespit edilmiştir. Bu araştırmalardan çıkan sonuçlar, bizim çalışmamızı desteklemektedir. Bu durum, öğrencilerin birçoğunun afet durumunda ne yapacağını bilmediğini ve afet konusunda bilinç düzeylerinin yetersiz olduğunu düşündürmektedir.

Çalışmamızda ikinci sınıfta olan öğrencilerin \%26.8 oranında diğer sınıflarda olan öğrencilere göre daha yüksek oranda yaşadıkları yerde afet acil durum çantası bulundurdukları saptanmıştır. Ayrıca ikinci sınıfta olan öğrencilerin \%17.9 oranında diğer sınıflarda olan öğrencilere göre daha yüksek oranda kendilerinin ve çevrelerinin afete hazırlıklı olduğunu düşündükleri belirlenmiştir. Kişilerin afet gibi öngörülemeyen olaylarla başa çıkabilme konusundaki davranışları, bu duruma hazırlıklı olma, bilgi ve bilinç düzeyleri ile yakından ilişkilidir (Arslan, 2016). Yapılan bir çalışmada afetlerle ilgili eğitim alanların, afet acil durum çantasına sahip olma oranlarının daha yüksek olduğu görülmüştür (Meral, 2014). Çalışmamızda dördüncü sınıftaki öğrencilerin diğer sınıflarda okuyan öğrencilere göre afetle ilgili daha yüksek oranda eğitimli olmalarına ve meslek hayatına kısa bir süre sonra atılacak olmalarına rağmen sosyokültürel düzeyi yüksek bu grubun afet öncesi önlemleri ihmal ettikleri ve yeterli önemi vermedikleri şeklinde düşünülmektedir.

Afetlere karşı bireysel hazırlığın toplumsal hazırlığa dönüşebileceğini düşünme durumunda öğrencilerin çekimser kaldıkları görülmektedir. Afet yönetimini bir disiplin olarak görecek bir 
kültürün yerleşmediği ülkemizde ne yazık ki doğal afetlerin önlenmesi ve zararlarının azaltılması mümkün değildir (Uzunçıbuk, 2005). Yapılan bir çalışmada afet risk algısının geliştirilmesinde hükümet planında eğitim, araştırma, sağlık ve kültür gibi farklı alanlarda, özellikle ailenin sosyal gruplarına vurgu yapmasını gerektirdiği sonucu bulunmuştur (Seyedin vd., 2019). Başka bir çalışmada ise araştırmaya katılan ortopedik engelli kişilerin acil durumlara/afetlere bireysel hazırlık yapmanın ölüm riskini azaltamayacağını, ihtiyaçlara karşılık veremeyeceğini ve aile bireylerini de koruyamayacağını düşündükleri yönünde farklı bir bakış açılarının olduğu tespit edilmiştir (Yılmaz vd., 2019). Bugüne kadar izlenen "afetler olduktan sonra olayın yarasını sarmaya çalışma" politikasının yerine, afetlerin neden olabileceği zararların fiziksel boyutlarını en düşük düzeyde tutacak tüm bilimsel, teknik, yönetsel ve yasal önlemleri afetler olmadan önce almayı amaçlayan bir süreç olmalıdır. Bu süreçte, afet yönetiminin devamlılığının esas alınmasının ülke, bölgesel ve yerel düzeyde ve halk katılımının sağlandığı bir "afet ve risk yönetiminin" oluşturulmasının yararlı olacağı değerlendirilmektedir (Uzunçıbuk, 2005). Bu bilgiler ışığında, afet ve risk yönetiminde bireysel katkının toplumsal hazırlığa dönüşümünde faydalı olacağına inanmaktayız.

\section{SONUÇ VE ÖNERILER}

Çalışmamızda hemşirelik öğrencilerinin afet konusunda bilgili oldukları görüldü. Ancak yüksek bir oranda kendilerinin ve çevresinin afetlere hazırlıklı olmamasına, yaşanılan yerde afet acil durum çantasının olmamasına ve alternatif barınma imkanlarının olmamasına bağlı olarak öğrencilerin bilinç düzeylerinin yetersiz olduğu görüldü. Ülke olarak deprem gerçeği ile karşı karşıya olmamıza rağmen ve bulunduğumuz ilinde 3 . derecede deprem bölgesinde olmasına rağmen öğrencilerin de bu deprem gerçeğini yeterince önemsemediklerini söyleyebiliriz.

Elde edilen veriler ışığında, afet ile ilgili eğitim konularının sadece Hemşirelik Bölümü ile sınırlı kalmaması, afet bilincinin ve sağlıklı bir afet yönetiminin sağlanması için diğer bölümlerin ders müfredatlarına konulması gerektiğini düşünmekteyiz. Afetlerle ilgili verdiğimizin eğitimin kalitesini arttırmakta da biz eğitimcilere büyük sorumluluklar düşmektedir. Afetlere karşı oluşturulacak ulusal bilincin ilköğretim çağındaki çocuklardan başlanarak toplumun bütün yaş kademelerine verilmesinin faydalı olacağına inanmaktayız. Ayrıca ulusal politikalar ile birlikte toplumun kültürel yapısını da göz önünde bulundurarak halkın da katılımının sağlandığı stratejilerin geliştirilmesinin etkili bir afet ve risk yönetimi ve afet bilinci sağlayacağı düşüncesindeyiz.

\section{Araştırmanın sınırlılıkları}

Araştırma sonuçları araştırmanın yapıldığı örnekleme ilişkin olduğundan genellenemez. Araştırma verileri toplanırken bir takım sıkıntılar ile karşılaşıldı. Öğrencilerin sık sık anket doldurma durumunda kalmaları gerekçesi ile anketleri yanıtlamada isteksiz davrandıkları gözlendi. 


\section{KAYNAKLAR}

Altıntaş, K. H. (2005). Afet tıbbında eğitim ve öğretim. Hacettepe Tıp Dergisi. 36(3):139-146. AFAD- Hakkında, https://www.afad.gov.tr/tr/2211/AFAD-Hakkinda [Erişim Tarihi:09.09.2019]. Sağlık Organizasyonu http://www.saglik.gov.tr/extras/birimler/apk/afetlerde saglik organizasyonu.zip [Erişim Tarihi:03.02.2020].

Arslan, E. (2016). Trakya Üniversitesi Tıp Fakültesi öğrencilerinin afet-acil durumlar hakkında bilgi tutum ve davranışlarının değerlendirilmesi (Yayınlanmamış Uzmanlık Tezi). Trakya Üniversitesi Tıp Fakültesi Acil Tıp Anabilim Dalı, Edirne.

Aslan, D. (2009). Halk sağlığı ile ilgili güncel sorunlar ve yaklaşımlar. Ankara Tabipler Odası Yayınları. 25-45.

Başeğmez, D. (2017). Hastanelerde Afet Yönetimine Illişkin Mevcut Durumun Değerlendirilmesi (Balıkesir Örneği) (Yayınlanmamış Yüksek Lisans Tezi). Okan Üniversitesi Sağlık Bilimleri Enstitüsü.

Erkal, T., Değerliyurt, M. (2009). Türkiye'de afet yönetimi. Doğu Coğrafya Dergisi. 14(22): 147-164.

Gaziantep İ Çevre Durum Raporu, 2010

https://webdosya.csb.gov.tr/db/gaziantep/webmenu/webmenu4769.pdf [Erişim Tarihi: 09.09.2019].

Güler, Ç., Akın, L. (2015). Halk Sağlığı Temel Bilgiler. Cilt 2, Baskı 3, Hacettepe Üniversitesi Yayınları, Ankara. 1106-1111.

Gülkan, P., Balamir, M., Yakut, A. (2003). Afet yönetiminin stratejik ilkeleri: Türkiye ve dünyadaki politikalara genel bakış. Orta Doğu Teknik Üniversitesi Afet Yönetimi Uygulama ve Araştırma Merkezi Yayınları, s. 4.

Işık, Ö., Aydınlıoğlu, H.M., Koç, S., Gündoğdu, O., Korkmaz, G., Ay, A.(2012). Afet yönetimi ve afet odaklı sağlık hizmetleri. Okmeydanı Tıp Dergisi. 28(2):82-123.

İnal, E., Kocagöz, S., Turan, M. (2012). Temel afet bilinç ve hazırlık düzeyinin saptanmasına yönelik bir araştırma. Türkiye Acil Tıp Dergisi - Tr J Emerg Med. 12(1):15-19.

Limoncu, S., Bayülgen, C. (2005). Türkiye'de afet sonrası yaşanan barınma sorunları, YTÜ Mim. Fak. e-Dergisi. 1(1):18-27.

Meral C. (2014). Gümüşhane Illinin Köse Illçesinde Halkın Afet Konusundaki Bilgi ve Bilinç Düzeylerinin Tespiti Araştırması (Yayınlanmamış Yüksek Lisans Tezi). Gümüşhane Üniversitesi Sosyal Bilimler Enstitüsü.

Mortelmans, L.J., Dieltiens, G., Anseeuw, K., Sabbe, M. (2013). Belgian senior medical students and disaster medicine: a real disaster?. Acta clinica Belgica. 68(6):484-487.

Mortelmans, L.J., Bouman, S.J., Gaakeer, M.I., Dieltiens, G., Anseeuw, K., Sabbe, M.B.(2015) Dutch senior medical students and disaster medicine: A national survey. Int J Emerg Med. 8(1):34.

Seyedin, H., Samadipour, E., Salmani, I. (2019). Intervention strategies for improvement of disasters risk perception: Family-centered approach. Journal of education and health promotion, 8;1-12. 
Sevinç, Ö., Güner, Y., Til, A. (2018). Çanakkale ili 112 acil sağlık hizmetleri istasyonlarında çalışan personelin afet tıbbı konusundaki bilgi düzeyleri. Pamukkale Tıp Dergisi. 11(2):119125.

Ronan, K. R. (2001). School children's risk perception and preparedness: a hazard education survey. The Australasian Journal of Disaster and Trauma Studies.

Ronan, K. R., Johnston, D. M. (2003). Hazards education for youth: A quasi-experimental investigation. Risk Analysis: An International Journal, 23(5):1009-1020.

Türkiye, Afet Farkındalığı ve Afetlere Hazırlık Araştırması, 2014. Ankara: Afet ve Acil Durum Yönetim Başkanlığı. https://www.afad.gov.tr/upload/Node/3923/xfiles/turkiye-afet-farkindaligive-afetlere-hazirlik-arastirmasi -2014-edited.pdf [Erişim Tarihi:09.09.2019].

UMKE Tarihçesi, https://www.umke.org/umke-tarihcesi-s14.html [Erişim Tarihi:09.09.2019].

Uzunçıbuk, L. (2005). Yerleşim Yerlerinde Afet ve Risk Yönetimi (Yayınlanmamış Doktora Tezi). Ankara Üniversitesi Sosyal Bilimler Enstitüsü.

Yavuz, Ö. (2014). Afetler sonrası yapılan sosyal yardımlar ve hizmetler. İdeal Kültür \& Yayıncılık, İstanbul. 19-38.

Yılmaz, A. (2012). Türkiye'de afetlerde karşılaşılan sorunlar. Manas Sosyal Araştırmalar Dergisi. 1(1):61-81.

Yılmaz, K., Balun, B., Erbay, G. (2019). Sürdürülebilir bir yönetim paradigması: Ortopedik engelli bireylerin afetlere hazırlık seviyeleri. Resilience Journal / Dirençlilik Dergisi, 3(1):1-24. 